\title{
Struktur dan Komposisi Vegetasi di Habitat Cemara Laut (Casuarina equisetifolia L.) pada Tiga Kawasan Konservasi di Provinsi Bengkulu
}

\author{
Structure and composition of vegetation in sheoak (Casuarina equisetifolia L.) habitat in three \\ conservation areas of Bengkulu Province
}

\author{
Albert Farma ${ }^{\mathrm{a}}$, Agus Hikmat ${ }^{\mathrm{b}}$, Rinekso Soekmadi ${ }^{\mathrm{b}}$

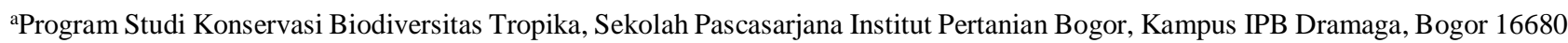 \\ bepartemen Konservasi Sumberdaya Hutan dan Ekowisata, Fakultas Kehutanan, Institut Pertanian Bogor, Kampus IPB Darmaga, \\ Bogor 16680
}

\section{Article Info:}

Received: 13 - 02 - 2018

Accepted: 23 - 03 - 2018

\section{Keywords:}

Composition, diversity, sheoak (Casuarina equisetifolia L.)

habitat, structure

Corresponding Author:

Albert Farma

Program Studi Konservasi

Biodiversitas Tropika, Sekolah

Pascasarjana Institut Pertanian

Bogor, Kampus IPB Dramaga,

Bogor;

Email:

albertfarma67@gmail.com

\begin{abstract}
Sheoak (Casuarina equisetifolia L.) is a species of monotypic taxa that has grown naturally in coastal Bengkulu Province. However, the various dynamics occurring in the coastal areas have disrupted the habitat of this species, affecting the structure and composi-tion of the vegetation. This research aims to analyze the structure and composition of vegetation in sheoak habitat in three conser-vation areas. The vegetation data was collected by line transect plot method. The analysis showed that sheoak stands form an in-verted curve $J$ in three conservation areas although they were not perfect due to the low density of poles which can be caused by disturbances that come from nature and human activity. Vegetation composition in sheoak habitat was composed by 36 species of 27 plant families consisting of shrubs and trees. Sheoak dominated the three areas only at the rate of tree growth while the growth rates of seedlings, saplings and poles were dominated by nyamplung (Calophyllum inophyllum) so the dominance of sheoak can be replaced with nyamplung. Sheoak also supported better habitat for other plant species to grow that showed diversity index value 1.4 to 1.9.
\end{abstract}

How to cite (CSE Style $8^{\text {th }}$ Edition):

Farma A, Hikmat A, Soekmadi R. Struktur dan Komposisi Vegetasi di Habitat Cemara Laut (Casuarina equisetifolia L.) pada Tiga Kawasan Konservasi di Provinsi Bengkulu. JPSL 9(3): 596-607. http://dx.doi.org/10.29244/jps1.9.3.596-607.

\section{PENDAHULUAN}

Cemara laut (Casuarina equisetifolia L) merupakan spesies dari monotypic taxa yang divalidasi oleh Linnaeus pada tahun 1759 (Koorders 1909; Friis 1980). Spesies dari monotipik taksa penting untuk mendapatkan perhatian konservasi karena mewakili spesies yang dapat punah (Golam dan Araki 2010). Kemudian monotipik taksa menjadi salah satu kriteria pertimbangan untuk menentukan tingginya nilai konservasi suatu spesies karena diversitas geneticnya yang rendah (Farjon dan Page 1999). Selain itu regenerasi alami cemara laut tergolong rendah karena viabilitas benihnya yang kecil yaitu 7\% sampai $16 \%$ (Eze dan Ahonsi 1993). Oleh karena itu penting untuk mengkonservasi spesies ini di habitatnya.

Cemara laut tumbuh alami di wilayah pesisir yang dinilai miskin unsur hara dan air. Untuk dapat tumbuh pada daerah tersebut spesies ini bersimbiosis dengan bakteri Frankia sehingga memiliki nodul akar yang dapat memfiksasi nitrogen secara lansung (Torrey 1982; Diagne et al. 2013; Karthikeyan 2016). Selain itu symbiosis ini meningkatkan unsur hara tanah sehingga dapat mendukung lingkungan yang lebih baik untuk pertumbuhan spesies lainnya (Diem et al. 2000; Diagne et al. 2013; Karthikeyan et al. 2009). 
Berbagai manfaat diberikan cemara laut. Menurut Nuitja dan Lazell (1982) vegetasi cemara laut di Provinsi Bengkulu menjadi lokasi bertelurnya penyu belimbing yang dinilai telah terancam punah. Spesies ini diintroduksikan ke Texas sebagai spesies pelindung dan pendukung ekosistem (Liu et al. 2015). Cemara laut menjadi sumber pemenuhan kebutuhan kayu di Afrika (Diagne et al. 2013). Meskipun demikian, spesies ini kurang mendapatkan perhatian dihabitatnya karena adanya benturan kepentingan berbagai pihak.

Provinsi Bengkulu memiliki tiga kawasan konservasi di wilayah pesisir yang menjadi habitat cemara laut. Kawasan tersebut adalah Cagar Alam Air Rami 1, Cagar Alam Air Seblat, dan Taman Wisata Alam Pantai Panjang dan Pulau Baai. Ketiga kawasan tersebut tidak lepas dari gangguan yang dapat memberikan dampak negatif bagi tumbuhan yang berada di dalam kawasannya khususnya cemara laut.

Masalah kelestarian kini dihadapi cemara laut seperti penebangan pohon yang tidak terkendali, bencana alam, permukiman, perkebunan, dan pembangunan oleh pemerintah daerah. Secara langsung maupun tidak langsung masalah tersebut akan mempengaruhi komposisi dan struktur vegetasi cemara laut beserta spesies lain di sekitarnya sedangkan informasi tersebut belum diketahui. Dari masalah yang telah diungkapkan maka tujuan dari penelitian ini adalah menganalisis struktur, komposisi dan keanekaragaman vegetasi yang berada di dalam habitat cemara laut pada tiga kawasan konservasi di Provinsi Bengkulu. Dengan demikian, informasi yang dihasilkan dapat digunakan sebagai salah satu pertimbangan dalam pengambilan keputusan untuk mengkonservasi cemara laut di kemudian hari.

\section{METODE}

\section{Waktu dan Lokasi Penelitian}

Penelitian dilaksanakan selama bulan Maret-Mei 2017 di tiga kawasan konservasi yang berada di pesisir Provin-si Bengkulu. Ketiga kawasan tersebut yaitu Cagar Alam Air Rami 1, Cagar Alam Air Seblat, dan Taman Wisata Alam Pantai Panjang dan Pulau Baai yang dapat dilihat pada Gambar 1.

\section{Alat, Bahan dan Objek Penelitian}

Alat dan bahan yang digunakan adalah GPS Garmin etrex 30, peta kawasan, alat tulis, tally sheet, pita ukur, kamera digital, peralatan herbarium (alkohol 70\%, tag-in, koran, plastik spesimen), software Microsoft Excel dan Minitab 18. Objek penelitian yaitu vegetasi (semak, perdu dan pohon) yang berada di dalam habitat cemara laut.

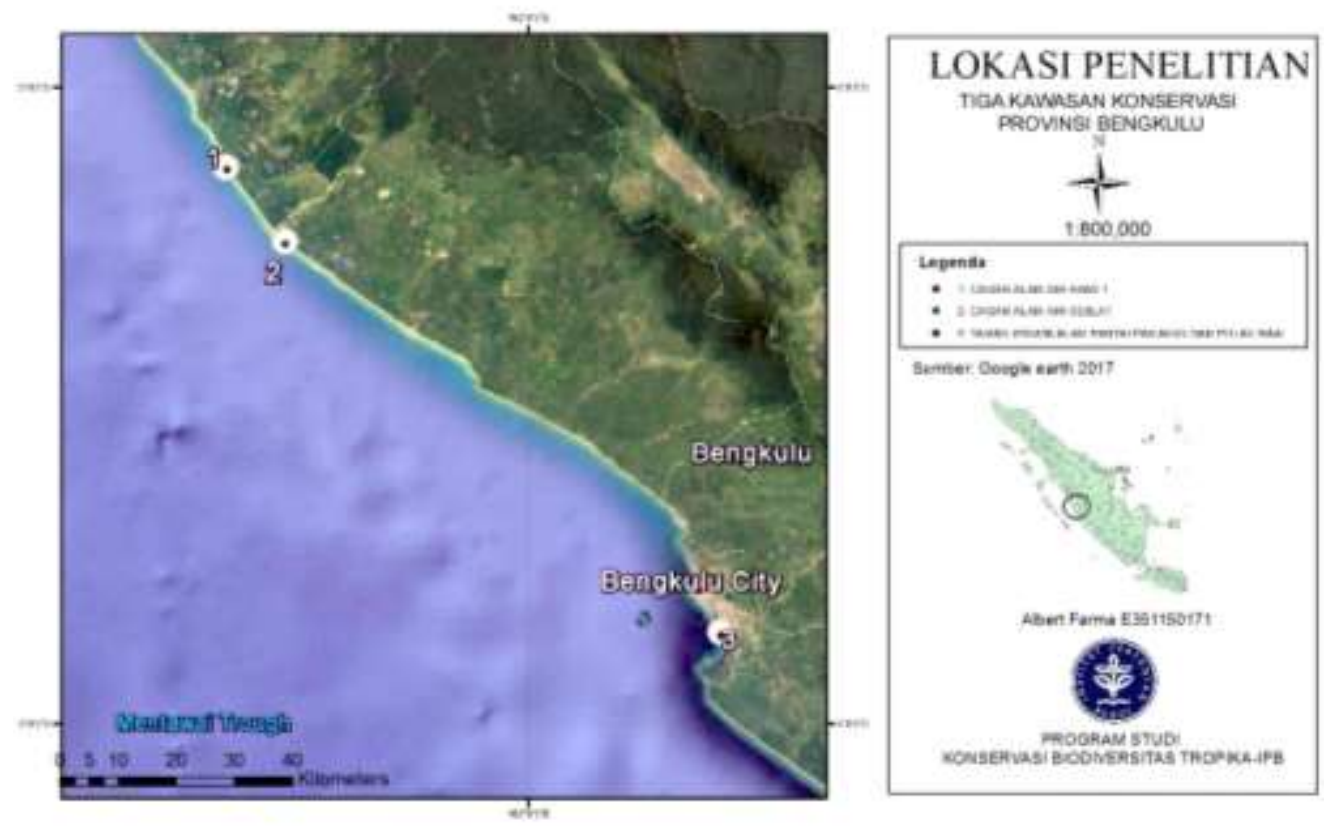

Gambar 1 Peta lokasi penelitian 


\section{Metode Pengumpulan Data}

Data vegetasi pada habitat cemara laut dikumpulkan dengan menggunakan metode jalur berpetak yang arah rintisannya tegak lurus dengan garis pantai. Jalur berpetak ini memiliki ukuran yaitu $20 \mathrm{~m}$ x $100 \mathrm{~m}$. Setiap jalur diulang secara sistematik dengan jarak antar jalur rintis sejauh $100 \mathrm{~m}$.

Analisis vegetasi dilakukan di setiap jalur yang dibagi menjadi beberapa petak contoh pengamatan. Petak contoh menurut tingkat pertumbuhan vegetasi yang diukur yaitu semai $(2 \mathrm{~m} \times 2 \mathrm{~m})$, pancang $(5 \mathrm{~m} \times 5 \mathrm{~m})$, tiang $(10 \mathrm{~m} \times 10 \mathrm{~m})$ dan pohon $(20 \mathrm{~m} \times 20 \mathrm{~m})$. Kriteria yang digunakan pada tingkat pertumbuhan yaitu semai (tinggi $<1.5 \mathrm{~m}$ ), pacang (tinggi di atas $1.5 \mathrm{~m}$ dengan diameter $<10 \mathrm{~cm}$ ), tiang $(10 \mathrm{~cm}>$ diameter $<20 \mathrm{~cm}$ ) dan pohon (diameter $>20 \mathrm{~cm}$ ) (Kusmana 1997).

\subsection{Metode Analisis Data}

Data vegetasi dianalisis dengan menggunakan analisis Indeks Nilai Penting (INP). Analisis INP didasarkan pada kerapan, frekuensi dan dominasi spesies pada suatu kawasan (Soerianegara dan Indrawan 1988). Nilai maksimal INP untuk tingkat pertumbuhan tiang dan pohon masing-masing bernilai $300 \%$ dengan menjumlahkan KR, FR dan DR. Kemudian maksimal nilai INP pada tingkat pertumbuhan semai dan pancang masing-masing bernilai $200 \%$ dengan menjumlahkan KR dan FR. Rumus perhitungan INP adalah sebagai berikut:

a. Kerapatan spesies $(K)=\sum$ individu suatu spesies / luas petak contoh

b. Kerapatan relatif $(\mathrm{KR})=(\mathrm{K}$ suatu spesies $/ \mathrm{K}$ total seluruh spesies $) \times 100 \%$

c. Frekuensi $(\mathrm{F})=\sum$ Sub petak ditemukan suatu spesies $/ \sum$ seluruh sub petak contoh

d. Frekuensi relatif $(\mathrm{FR})=(\mathrm{F}$ suatu spesies $/ \mathrm{F}$ total seluruh spesies $) \times 100 \%$

e. Dominasi $(\mathrm{D})=$ Luas bidang dasar suatu spesies / Luas petak contoh

f. Dominansi relatif $(\mathrm{DR})=(\mathrm{D}$ suatu spesies / $\mathrm{D}$ total seluruh spesies $) \times 100 \%$

Indeks keragaman spesies kemudian dihitung dengan menggunakan indeks diversitas Shannon-Wienwer (1949) $\left(H^{\prime}\right)$ dan indeks kemerataan Pielou (1975) (E) dalam Ludwig dan Reynold (1988). Persamaan kedua indeks tersebut yaitu:

Keterangan:

$$
H^{\prime}=-\sum_{i=1}^{S *}(p i \ln p i)
$$

$\mathrm{H}^{\prime}=$ indeks keanekaragaman

$\mathrm{pi}=$ proporsi spesies $(\mathrm{ni} / \mathrm{N})$

Keterangan:

$$
E=\frac{H^{\prime}}{\ln (S)}
$$

$E=$ Indeks kemerataan spesies

$S=$ jumlah spesies di suatu komunitas.

Analisis kluster dengan metode Ward (1963) dalam Romesburg (1984) digunakan untuk menilai kesamaan komunitas tiga kawasan konservasi. Metode ini menggabungkan dua kluster berdasarkan tingkat varians terkecil (Romesburg 1984; Everitt et al. 2011). Persamaan metode ini adalah sebagai berikut:

Keterangan:

$$
E_{m}=\sum_{i=1}^{n_{m}} \sum_{k=1}^{P k}\left(x_{m l, k}-\bar{x}_{m, k}\right)^{2}
$$

$E m \quad=$ jumlah kuadrad kesalahan kluster $m$ pada $k$ variable

$x_{m l, k}=$ skor yang dimiliki pada variabel $k \quad(k=1, \ldots, p)$ untuk objek $l\left(1=1, \ldots, n_{m}\right)$ pada kluster $(\mathrm{m}=1, \ldots, \mathrm{g})$ 


\section{HASIL DAN PEMBAHASAN}

\section{Struktur Vegetasi Cemara Laut}

Kelestarian cemara laut dapat dilihat dari struktur vegetasinya. Hasil penelitian menunjukkan bahwa kerapatan cemara laut berdasarkan tingkat pertumbuhan membentuk kurva $\mathbf{J}$ terbalik (Gambar 2) meskipun tidak sempurna pada tingkat tiangnya. Kerapatan tiang cemara di Cagar Alam Air Rami 1, Cagar Alam Air Seblat, dan Taman Wisata Alam Pantai Panjang dan Pulau Baai secara berurutan yaitu 30, 45 dan 18 individu per hektar, sedangkan kerapatan pada tingkat pohon lebih besar yaitu mencapai 60, 54 dan 67 individu per hektar. Rendahnya kerapatan tiang dibanding pohon menunjukkan bahwa vegetasi cemara laut mengalami gangguan di habitatnya. Meskipun demikian, kelestarian cemara laut masih dapat terjaga karena kerapatan permudaanya yang banyak yaitu pada tingkat semai dan pancang.

Kerapatan cemara laut yang rendah pada tingkat pertumbuhan tiang dapat dipengaruhi oleh faktor internal yaitu fisiologis tumbuhan terhadap lingkungan. Permudaan spesies ini pada tingkat semai dan pancang ditemukan tumbuh pada formasi terdepan penyusun vegetasi pantai yang dipengaruhi langsung oleh cahaya matahari dan salinitas. Seperti yang diungkapkan oleh Koorders (1909) bahwa cemara laut pada umumnya tumbuh alami dengan kondisi penuh cahaya dan tidak ditemukan pada kondisi vegetasi yang rapat. Kemudian perakarannya yang dangkal menyebabkan spesies ini mudah tumbang. Selain itu cemara yang tidak membentuk nodul akar lebih rentan terhadap salinitas (Diem et al. 2000).

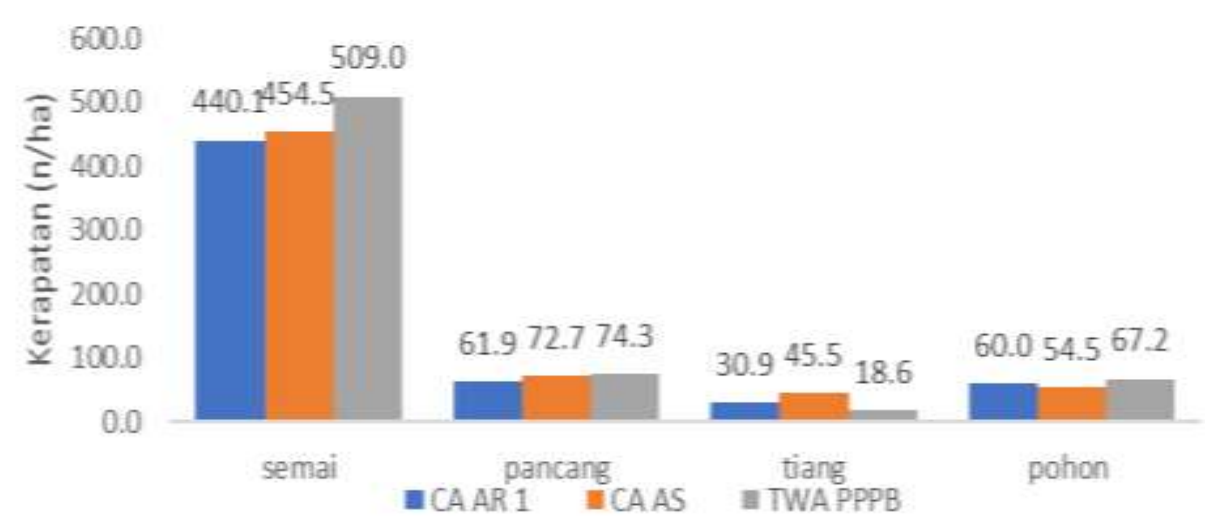

Gambar 2 Kerapan cemara laut berdasarkan tingkat pertumbuhan di tiga kawasan konservasi

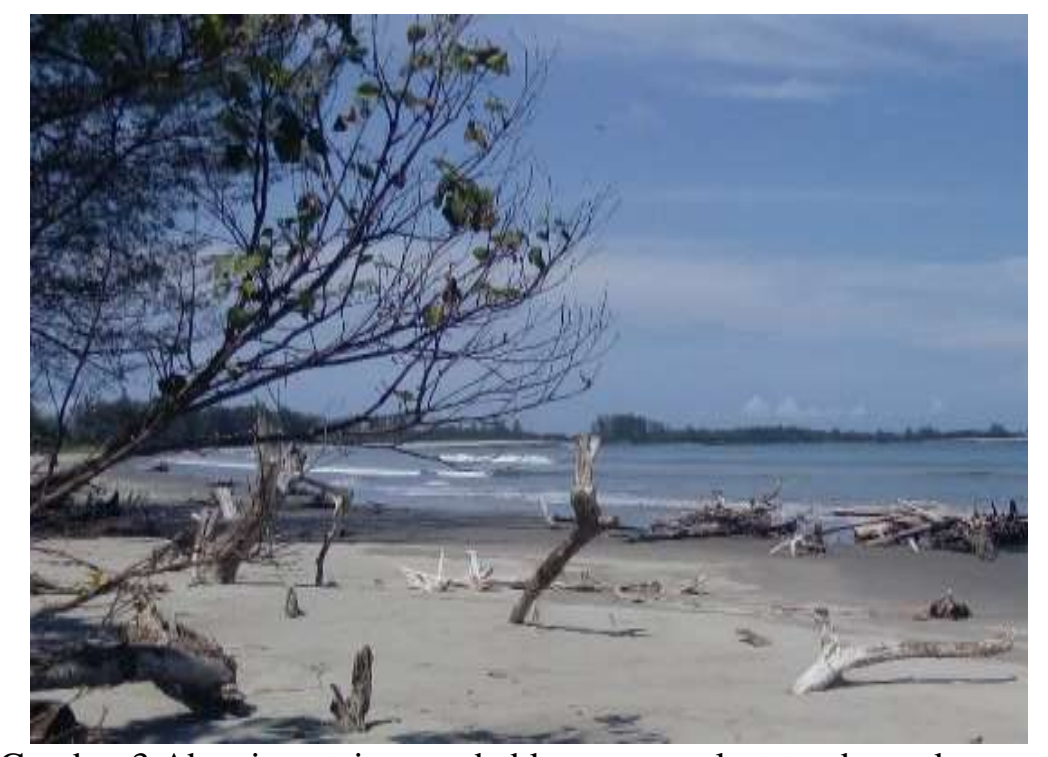

Gambar 3 Abrasi pantai menyebabkan cemara laut tumbang dan mati 
Faktor eksternal berupa gangguan dari alam dan manusia juga mempengaruhi kerapatan cemara di habitatnya. Pada Gambar 3 dapat dilihat bahwa bencana abrasi merusak vegetasi cemara laut sehingga cemara tumbang dan mati. Suwarsono et al. (2011) mengungkapkan bahwa abrasi yang terjadi di Provinsi Bengkulu merupakan bencana alam yang terjadi sepanjang tahun dan sulit untuk diatasi dengan kecepatan yang bervasiasi antara 0.5 sampai $2.5 \mathrm{~m}$ per tahun. Abrasi yang terus terjadi tidak lepas dari posisi habitat cemara laut yang menghadap langsung ke Samudera Hindia sehingga terus dipengaruhi gelombang perairan yang tinggi. Selain itu, masyarakat juga memanfaatkan cemara laut karena kayunya yang kuat, lurus dan panjang. Kayu cemara pada ukuran tertentu yaitu pancang dan tiang lebih banyak dimanfaatkan dibandingkan dengan ukuran yang lebih besar yaitu pohon karena kemudahan dalam pengelolaannya. Pancang dan tiang cemara umumnya dilakukan sebagai kayu konstruksi tiang rumah, rangka atap rumah, tiang kapal dan penyeimbang kapal.

\section{Komposisi vegetasi}

Hasil penelitian menunjukkan bahwa vegetasi di tiga habitat cemara laut teridentifikasi memiliki 36 spesies dari 27 famili. Vegetasi tersebut terdiri atas speseis pohon, semak dan perdu. Famili dengan spesies terbanyak ditemukan yaitu Leguminosae dengan 4 spesies. Famili terbanyak ditemukan selanjutnya yaitu Apocynaceae, Compositae, Lamiaceae, Malvaceae, Moraceae dengan masing - masing memiliki 2 spesies. Spesies dari famili Leguminosae yang teridentifikasi adalah Erythrina variegata, Acacia auricuiformis, Caesalpinia bonduc dan Desmodium umbrellatum. Spesies dari famili Leguminosae banyak ditemukan tumbuh karena memiliki kemampuan memfiksasi nitrogen sehingga mampu tumbuh dengan baik pada lingkungan yang kurang mendukung pertumbuhan. Komposisi vegetasi di dominasi juga oleh spesies dari Leguminosae dengan 18 spesies yang kebanyakan berupa spesies pohon di Hutan Zaraninge, Tanzania (Mligo et al.2009). Tidak hanya itu, cemara laut dari famili Casuarinaceae juga memiliki kemampuan memfiksasi nitrogen melalui nodul akarnya sehingga tumbuh baik di kawasan pesisir dan toleran terhadap salinitas (Diagne et al. 2013; Ngom et al. 2016). Menurut Gould et al. (2006) variasi spesies di dalam komposisi hutan pantai lahan basah sangat dipengaruhi oleh salinitas dan pada kawasan bukit pantai subtropik dengan iklim kering dipengaruhi oleh musim.

Hasil perhitungan INP untuk tingkat pertumbuhan pohon yang dapat dilihat pada Tabel 1. Cemara laut memiliki nilai INP tertinggi di tiga kawasan konservasi yaitu $149.88 \%$, 99.64\% dan $162.0 \%$. Pada tingkat pertumbuhan ini, tingginya nilai INP cemara disebabkan karena jumlah individu, kerapatan dan dominansi yang relatif lebih lebih tinggi dari spesies lainnya. Dengan demikian pada tingkat pertumbuhan pohon didominansi oleh cemara laut.

Tabel 1 INP lima spesies tertinggi pada tingkat pertumbuhan pohon pada tiga kawasan konservasi

\begin{tabular}{|c|c|c|c|c|c|c|}
\hline No & Nama latin & Nama lokal & KR (\%) & FR $(\%)$ & DR $(\%)$ & INP $(\%)$ \\
\hline \multicolumn{7}{|c|}{ Cagar Alam Air Rami 1} \\
\hline 1 & Casuarina sequisetifolia & Cemara laut & 50.67 & 35.79 & 63.42 & 149.88 \\
\hline 2 & Calophyllum inophyllum & Nyamplung & 13.08 & 17.37 & 14.03 & 44.47 \\
\hline 3 & Terminalia catappa & Ketapang & 11.59 & 13.68 & 7.92 & 33.2 \\
\hline 4 & Hibiscul tilliaceus & Waru & 10.55 & 14.47 & 7.77 & 32.8 \\
\hline 5 & Cerbera manghas & Bintaro & 10.25 & 12.89 & 4.93 & 28.08 \\
\hline \multicolumn{7}{|c|}{ Cagar Alam Air Seblat } \\
\hline 1 & Casuarina equisetifolia & Cemara laut & 38.71 & 26.47 & 34.46 & 99.64 \\
\hline 2 & Calophyllum inophyllum & Nyamplung & 17.74 & 20.59 & 27.75 & 66.08 \\
\hline 3 & Terminalia catappa & Ketapang & 12.9 & 17.65 & 13.26 & 43.81 \\
\hline 4 & Cocos nucifera & Kelapa & 14.52 & 11.76 & 7.13 & 33.41 \\
\hline 5 & Hibiscus tiliaceus & Waru & 8.06 & 11.76 & 6.89 & 26.72 \\
\hline \multicolumn{7}{|c|}{ Taman Wisata Alam Pantai Panjang dan Pulau Baai } \\
\hline 1 & Casuarina equisetifolia & Cemara laut & 50.85 & 36.66 & 74.49 & 162 \\
\hline
\end{tabular}




\begin{tabular}{lllllll}
\hline No & Nama latin & Nama lokal & KR $(\%)$ & FR $(\%)$ & DR $(\%)$ & INP $(\%)$ \\
\hline 2 & Calophyllum inophyllum & Nyamplung & 16.53 & 20.65 & 9.79 & 46.97 \\
3 & Hibiscus tiliaceus & Waru & 10.65 & 13.23 & 5.36 & 29.24 \\
4 & Terminalia catappa & Ketapang & 10.31 & 13.69 & 4.71 & 28.7 \\
5 & Cerbera manghas & Bintaro & 6.34 & 8.58 & 2.8 & 17.73 \\
\hline
\end{tabular}

Pohon cemara laut dominan tumbuh alami di tiga daerah pesisir. Kemampuan tumbuh tersebut tidak lepas dari peran nodul akar. Cemara laut bersimbiosis dengan bakteri Frankia untuk memiliki nodul akar yang mampu menyerap nitrogen langsung sehingga meningkatkan produktivitasnya (Diagne et al. 2013; Karthikeyan 2016; Torrey 1982). Kemudian keberadaan Frankia menjadi indikator penting untuk meningkatkan daya hidup cemara laut terutama pada lingkungan yang tercemar (Karthikeyan et al. 2009). Dominasi cemara merupakan hasil dari kemampuannya dalam memanfaatkan ruang tumbuh, cahaya, air dan unsur hara lebih baik. Oleh karena itu cemara laut dapat mendominasi kawasan pesisir yang dinilai kurang mampu mendukung spesies lainnya untuk tumbuh lebih baik. Keberadaan spesies pada suatu komunitas pada kondisi lingkungan yang tidak stabil merupakan hasil interaksi yang kompleks (Maun 2009).

Spesies pada tingkat permudaan tiang tidak didominansi oleh cemara laut akan tetapi didominasi oleh nyamplung (Calophyllum inophyllum) yang dapat dilihat pada Tabel 2. Nyamplung (C. inophyllum) memiliki nilai INP tertinggi di tiga kawasan konservasi secara berurutan yaitu $75.25 \%, 92.88 \%$ dan $86.92 \%$, sedangkan cemara laut (C. equisetifolia) memiliki nilai INP yang rendah yaitu $44.4 \%, 50.9 \%$ dan $35.7 \%$. Rendahnya nilai INP cemara laut pada tingkat pertumbuhan ini menunjukkan bahwa pertumbuhan cemara laut tidak lebih baik dibandingkan dengan nyamplung. Ini disebabkan kerapatan, frekuensi dan dominansi yang relatif rendah. Selain itu dipengaruhi juga oleh ketersediaan cemara pada tingkat pertumbuhan pancang yang relatif rendah karena pancang yang sedikit juga menghasilkan sedikit individu pada tingkat pertumbuhan tiang.

Indeks Nilai Penting (INP) tingkat pertumbuhan pancang didominasi oleh spesies nyamplung (Calophyllum inophyllum) yaitu 56.5\%, 65.8\% dan 63.9\%, sedangkan cemara laut memiliki nilai INP rendah yaitu $23.7 \%, 17.69 \%$ dan $32.9 \%$ yang dapat dilihat pada Tabel 3. Rendahnya nilai INP cemara pada tingkat pertumbuhan ini disebabkan oleh faktor cahaya matahari. Umumnya pancang cemara ditemukan di barisan terdepan hutan yang mendekati pantai dengan intensitas cahaya tinggi (tidak ternaungi), sedangkan nyamplung pada tingkat pertumbuhan ini lebih adaptif sehingga dapat ditemukan dalam kondisi ternaungi dan tidak ternaungi. Selain itu cemara laut yang tidak memiliki nodul akar akan terhambat pertumbuhannya dan rentan terhadap lingkungan sekitar (Diem et al. 2000).

Tabel 2 INP lima spesies tertinggi pada tingkat pertumbuhan tiang pada tiga kawasan konservasi

\begin{tabular}{lllllll}
\hline No & Nama latin & Nama lokal & KR $(\%)$ & FR (\%) & DR (\%) & INP (\%) \\
\hline Cagar Alam Air Rami 1 & & & & & \\
\hline 1 & Calophyllum inophyllum & Nyamplung & 25.58 & 24.8 & 24.87 & 75.25 \\
2 & Hibiscul tilliaceus & Waru & 18.6 & 18.4 & 17.84 & 54.85 \\
3 & Cerbera manghas & Bintaro & 16.94 & 17.2 & 17.17 & 51.32 \\
4 & Terminalia catappa & Ketapang & 15.28 & 16 & 16.34 & 47.62 \\
5 & Casuarina sequisetifolia & Cemara laut & 14.62 & 14.8 & 14.93 & 44.35 \\
\hline Cagar Alam Air Seblat & & & & & \\
\hline 1 & Calophyllum inophyllum & Nyamplung & 32.14 & 28.57 & 32.16 & 92.88 \\
2 & Cerbera manghas & Bintaro & 17.86 & 19.05 & 16.03 & 52.94 \\
3 & Terminalia catappa & Ketapang & 14.29 & 19.05 & 17.75 & 51.09 \\
4 & Casuarina equisetifolia & Cemara laut & 17.86 & 14.29 & 18.77 & 50.91 \\
5 & Cocos nucifera & Kelapa & 10.71 & 9.52 & 10.55 & 30.79 \\
\hline Taman Wisata Alam Pantai Panjang dan Pulau Baai & & & & \\
\hline 1 & Calophyllum inophyllum & Nyamplung & 28.23 & 29.38 & 29.31 & 86.92 \\
2 & Hibiscus tiliaceus & Waru & 15.32 & 14.95 & 16.07 & 46.34 \\
3 & Cerbera manghas & Bintaro & 15.32 & 15.98 & 14.68 & 45.99 \\
4 & Terminalia catappa & Ketapang & 12.5 & 13.92 & 11.95 & 38.37 \\
5 & Casuarina equisetifolia & Cemara laut & 12.5 & 10.82 & 12.37 & 35.69 \\
\hline
\end{tabular}


Tabel 3 INP lima spesies tertinggi pada tingkat pertumbuhan pancang pada tiga kawasan konservasi

\begin{tabular}{llllll}
\hline No & Nama latin & Nama lokal & KR $(\%)$ & FR (\%) & INP (\%) \\
\hline Cagar Alam Air Rami 1 & & & & \\
\hline 1 & Calophyllum inophyllum & Nyamplung & 30.13 & 26.4 & 56.53 \\
2 & Cerbera manghas & Bintaro & 20.51 & 22.4 & 42.91 \\
3 & Terminalia catappa & Ketapang & 16.03 & 20 & 36.03 \\
4 & Hibiscul tilliaceus & Waru & 12.18 & 14.4 & 26.58 \\
5 & Casuarina sequisetifolia & Cemara laut & 14.1 & 9.6 & 23.7 \\
\hline Cagar Alam Air Seblat & & & & \\
\hline 1 & Calophyllum inophyllum & Nyamplung & 30.77 & 35 & 65.77 \\
2 & Cerbera manghas & Bintaro & 23.08 & 25 & 48.08 \\
3 & Terminalia catappa & Ketapang & 23.08 & 20 & 43.08 \\
4 & Hibiscus tiliaceus & Waru & 15.38 & 10 & 25.38 \\
5 & Casuarina equisetifolia & Cemara laut & 7.69 & 10 & 17.69 \\
\hline Taman Wisata Alam Pantai Panjang dan Pulau Baai & & & \\
\hline 1 & Calophyllum inophyllum & Nyamplung & 31.98 & 31.97 & 63.95 \\
2 & Cerbera manghas & Bintaro & 22.67 & 25.17 & 47.84 \\
3 & Casuarina equisetifolia & Cemara laut & 18.02 & 14.97 & 32.99 \\
4 & Terminalia catappa & Ketapang & 10.47 & 12.24 & 22.71 \\
5 & Hibiscus tiliaceus & Waru & 9.88 & 10.2 & 20.09 \\
\hline
\end{tabular}

Tabel 4. INP lima spesies tertinggi pada tingkat pertumbuhan semai pada tiga kawasan konservasi

\begin{tabular}{llllll}
\hline No & Nama latin & Nama lokal & KR (\%) & FR (\%) & INP (\%) \\
\hline Cagar Alam Air Rami 1 & & & & \\
\hline 1 & Calophyllum inophyllum & Nyamplung & 32.38 & 31.71 & 64.09 \\
2 & Casuarina sequisetifolia & Cemara laut & 23.81 & 19.51 & 43.32 \\
3 & Terminalia catappa & Ketapang & 17.14 & 20.73 & 37.87 \\
4 & Cerbera manghas & Bintaro & 18.1 & 18.29 & 36.39 \\
5 & Hibiscul tilliaceus & Waru & 8.57 & 9.76 & 18.33 \\
\hline Cagar Alam Air Seblat & & & & \\
\hline 1 & Calophyllum inophyllum & Nyamplung & 42.11 & 35.71 & 77.82 \\
2 & Cerbera manghas & Bintaro & 26.32 & 28.57 & 54.89 \\
3 & Terminalia catappa & Ketapang & 15.79 & 21.43 & 37.22 \\
4 & Casuarina equisetifolia & Cemara laut & 10.53 & 7.14 & 17.67 \\
5 & Hibiscus tiliaceus & Waru & 5.26 & 7.14 & 12.41 \\
\hline Taman & Wisata Alam Pantai Panjang & dan & & & \\
Pulau Baai & & & & \\
\hline 1 & Calophyllum inophyllum & Nyamplung & 33.33 & 33.95 & 67.28 \\
2 & Cerbera manghas & Bintaro & 16.91 & 19.14 & 36.04 \\
3 & Terminalia catappa & Ketapang & 13.53 & 16.67 & 30.19 \\
4 & Casuarina equisetifolia & Cemara laut & 16.43 & 13.58 & 30.01 \\
5 & Acacia auriculiformis & Akasia & 12.08 & 8.02 & 20.1 \\
\hline
\end{tabular}

Semai nyamplung mendominasi di tiga wilayah konservasi (Tabel 4) dengan nilai INP tertinggi yaitu $64.09 \%, 77.82 \%$ dan $67.28 \%$, sedangkan cemara laut pada tingkat pertumbuhan ini memiliki nilai INP yang rendah yaitu $43.32 \%, 17.67 \%$ dan $30.01 \%$ yang dapat dilihat pada Tabel 4 . Rendahnya INP semai cemara dipengaruhi oleh kondisi benih cemara yang tidak mampu berkecambah sehingga semai cemara yang tumbuh tidak sebanyak benih yang dihasilkannya. Umumnya benih yang ditemukan di lokasi penelitian dalam kondisi tidak berkecambah dan juga berada di dalam samaranya. Menurut Eze dan Ahonsi (1993) viabilitas benih cemara laut yang rendah yaitu $7 \%$ sampai $16 \%$ merupakan faktor yang mempengaruhi keberadaanya secara alami. Selain itu faktor lingkungan dapat mempengaruhi perbedaan respon semai cemara laut maupun nyamplung. 
Tabel 5. INP lima spesies tertinggi semak dan perdu pada tiga kawasan konservasi

\begin{tabular}{llllll}
\hline No & Nama latin & Nama lokal & KR $(\%)$ & FR $(\%)$ & INP $(\%)$ \\
\hline Cagar Alam Air Rami 1 & & & & \\
\hline 1 & Ficus septica & Awar-awar & 16.30 & 15.73 & 32.03 \\
2 & Macaranga tanarius & Mara & 13.91 & 12.10 & 26.01 \\
3 & Ardisia humilis & Lampeni & 8.91 & 12.10 & 21.01 \\
4 & Pandanus tectorius & Pandan laut & 10.65 & 6.85 & 17.51 \\
5 & Caesalpinia bonduc & Ketepeng cina & 6.96 & 6.85 & 13.81 \\
\hline Cagar Alam Air Seblat & & & & \\
\hline 1 & Lantana camara & Tai ayam & 24.07 & 20.59 & 44.66 \\
2 & Macaranga tanarius & Mara & 20.37 & 17.65 & 38.02 \\
3 & Ficus septica & Awar-awar & 11.11 & 14.71 & 25.82 \\
4 & Pandanus tectorius & Pandan laut & 16.67 & 5.88 & 22.55 \\
5 & Calotropis gigantea & Biduri & 9.26 & 11.76 & 21.02 \\
\hline Taman Wisata Alam Pantai Panjang dan Pulau Baai & & & \\
\hline 1 & Ardisia humilis & Lampeni & 21.88 & 21.16 & 43.04 \\
2 & Ficus septica & Awar-awar & 10.82 & 17.43 & 28.25 \\
3 & Macaranga tanarius & Mara & 13.41 & 12.03 & 25.44 \\
4 & Calotropis gigantea & Biduri & 11.53 & 6.22 & 17.75 \\
5 & Caesalpinia bonduc & Ketepeng cina & 7.76 & 6.64 & 14.40 \\
\hline
\end{tabular}

Nyamplung tumbuh pada kondisi lingkungan yang sama dengan cemara laut. Kedua spesies tersebut memiliki benih yang masa pertumbuhannya sama-sama dipengaruhi oleh salinitas. Peningkatan salinitas sebesar 75\%-100\% dapat meningkatkan daya kecambah benih nyamplung (Hanin 2011). Nyamplung juga tercatat sebagai spesies yang dominan tumbuh untuk setiap tingkat pertumbuhannya di Hutan Pantai Tanah Merah di Kalimantan Timur (Mukhlisi dan Sidiyasa 2011). Benih cemara laut juga dipengaruhi salinitas seperti yang diungkapkan oleh Tani dan Sasakawa (2003) bahwa benih cemara laut sangat toleran terhadap salinitas, namun dengan meningkatnya salinitas akan menurunkan laju perkecambahannya. Dengan demikian kedua benih spesies ini dapat memberikan respon yang berbeda terhadap peningkatan salinitas.

Terdapatnya vegetasi cemara laut diikuti juga dari tumbuhnya semak dan perdu di sekitarnya. Umumnya semak dan perdu yang tumbuh di tiga habitat cemara laut disusun oleh spesies yang hampir sama dengan dominansi yang berbeda (Tabel 5). Awar-awar (Ficus septica) merupakan spesies dengan nilai INP tertinggi di Cagar Alam Air Rami 1 dengan nilai INP yaitu 32\%. Tai ayam (Lantara camara) merupakan spesies dengan INP tertinggi di Cagar Alam Air Seblat dengan INP sebesar 44.6\%. Taman Wisata Alam Pantai Panjang dan Pulau Baai didominasi oleh lampeni (Ardisia humilis) dengan nilai INP yaitu 43\%. Meskipun demikian, spesies yang ditemukan tumbuh umum berasal dari genus yang sama hanya saja keberadaanya yang berbeda antar lokasi.

Spesies lain tumbuh bersama dengan cemara laut sehingga membentuk tegakan campuran. Ini tidak lepas dari dampak positif yang diberikan cemara laut untuk tumbuhan sekitarnya karena akumulasi biomassa dari spesies ini mampu meningkatkan unsur hara tanah. Menurut Jamaludheen dan Kumar (1999) serasah cemara laut meningkatkan unsur N, P dan K secara berturut-turun sebanyak 61, 1.2 dan $3.4 \mathrm{~kg} / \mathrm{ha} / \mathrm{th}$. Selain itu, ada kecenderung dominasi cemara akan terganti dengan spesies lain karena INP cemara yang relatifkecil pada tingkat semai, pancang dan tiang. Seperti yang dikemukakan oleh Tagawa et al. (1985) bahwa cemara laut merupakan spesies pionir yang mendominasi kawasan pantai di Pulau Sertung dengan keragaman yang rendah yang kemudian komposisinya cenderung berubah menjadi tegakan campuran setelah cemara tersebut mati atau tumbang seperti yang terjadi di Pulau Rakata Kecil. 


\section{Keanekaragaman spesies}

Indeks keanekaragamann dan kemerataan tumbuhan di tiga lokasi konservasi dapat dilihat pada Tabel 6. Cagar Alam Air Rami 1 (CAAR1) memiliki indeks keanekaragaman tertinggi pada tingkat pertumbuhan tiang yaitu 1.9, sedangkan indeks terendahnya pada tingkat pertumbuhan pohon yaitu 1.52. Cagar Alam Air Seblat (CAAS) memiliki indeks keanekaragaman tertinggi pada tingkat pertumbuhan tiang yaitu 1.7 sedangkan indeks terendahnya pada tingkat pertumbuhan semai yaitu 1.40. Kemudian Taman Wisata Alam Pantai Panjang dan Pulau Baai memiliki indeks keanekaragaman tertinggi pada tingkat pertumbuhan tiang yaitu 1.9 sedangkan indeks terendahnya pada tingkat pertumbuhan pohon yaitu 1.5. Indeks keanekaragaman spesies pohon di tiga kawasan ini dapat digolongkan ke dalam kategori rendah dan sedang dengan nilai indeks antara 1.4 sampai 1.9 .

Indeks keanekaragaman di tiga habitat cemara laut di Provinsi Bengkulu ini lebih tinggi dibandingkan dengan habitat mangrove di Pulau Rimau dengan nilai indeks pohon (0.34), pancang (0.88), semai (0.46) (Indriani et al.2009) dan juga di kawasan wisata Pasir Jambak dengan indeks pohon (0.33), sampling (0.46) dan seedling (0.77) (Samin et al. 2016). Akan tetapi indeks keanekaragamannya rendah bila dibandingkan dengan vegetasi di Gunung Dempo dengan indeks pohon (1.9) dan semai (3.7) Ismaini et al. (2015) dan juga pada kawasan hutan sekunder yaitu 3.41, 2.81 belukar tua, 2.07 belukar muda di area IUPHHK-RE PT REKI (Nurfatma et al. 2017). Perbedaan nilai indeks yang dihasilkan dipengaruhi oleh jumlah spesies dan banyaknya individu yang ditemukan pada habitat yang berbeda. Menurut Margalef (1972) dalam Magurran (2004), indeks diversitas Shannon biasanya memiliki nilai antara 1.5 sampai 3.5 dan jarang di atas 4 .

Tingkat pertumbuhan tiang memiliki nilai keragaman yang paling tinggi di tiga lokasi. Pada tingkat tiang ini, spesies yang tumbuh lebih beragam sehingga menghasilkan nilai yang besar karena pada tingkat pertumbuhan ini spesies telah beradaptasi meskipun faktor lingkungan sekitar masih mempengaruhinya. Tingkat pertumbuhan semai memiliki indeks yang rendah karena viabilitas benih dan faktor lingkungan mempengaruhi perkecambahan benih. Indeks keragaman pada tingkat pohon juga rendah dibandingkan tiang karena pada tingkat ini jumlah spesies dan individu yang berhasil tumbuh sedikit karena spesies yang telah adaptif terhadap perubahan lingkungan yang mempengaruhi perkembangannya.

Perbedaan jumlah individu dan spesies antar lokasi mempengaruhi indeks keanekaragaman dan kemerataan. Semakin tingginya indeks keragaman menandakan bahwa jumlah spesies yang ditemukan semakin banyak dan semakin tingginya indeks kemerataan menandakan bahwa penyebaran individu dalam suatu kawasan tersebut semakin merata. Spesies di tiga lokasi tersebar merata dengan nilai indeks yang mendekati 1 yaitu antara 0.7 (CA AR1), 0.9 (CA AS) dan 0.9 (TWA PPPB) yang dapat dilihat pada Tabel 6. Jumlah spesies pada suatu kawasan mempengaruhi kemerataan spesies (Ludwig dan Reynolds 1988). Indeks kemerataan yang tinggi pada kawasan Cagar Alam Air Seblat disebabkan oleh rendahnya jenis tumbuhan yang ditemukan, sedangkan dua kawasan lainnya memiliki keragaman jenis yang lebih tinggi. Kemerataan yang tinggi juga dimiliki hutan pinus di Taman Nasional Gunung Gede Pangrango karena memiliki sedikit tumbuhan (Gunawan et al. 2011).

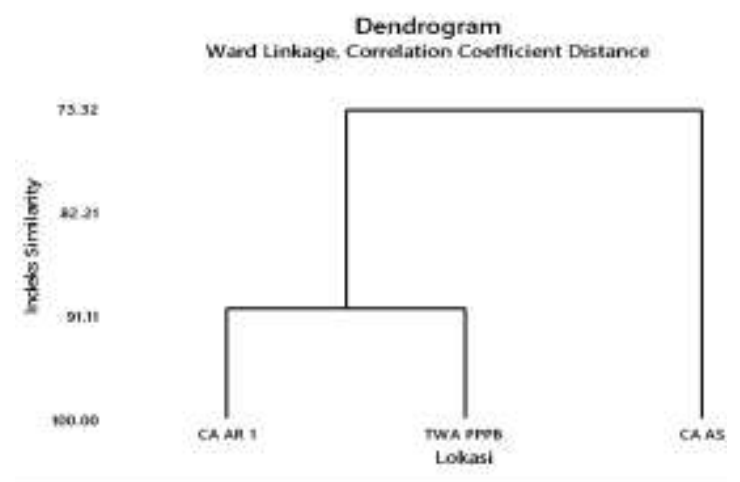

Gambar 4 Dendrogram kesamaan komunitas di tigahabitat cemara laut 
Tabel 6. Indeks diversitas (H') dan kemerataan spesies (E) di tiga kawasan konservasi

\begin{tabular}{|c|c|c|c|c|c|c|c|}
\hline \multirow[t]{2}{*}{ No } & \multirow[t]{2}{*}{ Tingkat Pertumbuhan } & \multicolumn{2}{|c|}{ CAAR 1} & \multicolumn{2}{|c|}{ CAAS } & \multicolumn{2}{|c|}{ TWAPPPB } \\
\hline & & $H^{\prime}$ & $E$ & $H^{\prime}$ & $E$ & $H^{\prime}$ & $E$ \\
\hline 1 & Pohon & 1.52 & 0.63 & 1.62 & 0.91 & 1.50 & 0.65 \\
\hline 2 & Tiang & 1.90 & 0.79 & 1.69 & 0.94 & 1.88 & 0.90 \\
\hline 3 & Pancang & 1.82 & 0.76 & 1.52 & 0.95 & 1.70 & 0.87 \\
\hline 4 & Semai & 1.53 & 0.95 & 1.40 & 0.87 & 1.71 & 0.88 \\
\hline
\end{tabular}

Keterangan: CAAR 1= Cagar Alam Air Rami 1, CA AS= Cagar Alam Air Seblat, TWA PPPB= Taman Wisata Alam Pantai Panjang dan Pulau Baai

Faktor lain yang mempengaruhi perbedaan indeks di tiga kawasan ini dapat juga berasal dari luas kawasan dan tingkat gangguan yang berbeda antar kawasan. Kawasan Cagar Alam Air Seblat merupakan kawasan konservasi yang berada di Bengkulu Utara yang luasnya lebih kecil dibandingkan dua kawasan lainnya dan sering mendapatkan gangguan abrasi dan pasang air laut. Seperti yang diterangkan oleh Suwarsono et al (2011), wilayah pesisir di Bengkulu Utara merupakan daerah yang mengalami tingkat abrasi yang besar. Selain itu, homogenitas spesies pada suatu kawasan dapat mempengaruhi rendahnya indeks keanekaragaman dan dapat meningkatkan indeks kemerataan sehingga indeks-indeks ini dapat ditemukan pada kawasan hutan tanaman dan kawasan yang hanya memiliki beberapa spesies karena sebab lainnya seperti spesies invasif yang memiliki daya penyebaran dan tempat tumbuh yang mendominasi. Master et al (2013) menjelaskan bahwa hutan yang telah diinvasi oleh mantangan (Merremia peltata) memiliki indeks diversitas yang lebih rendah dari hutan primer dan sekunder yaitu 1.90 karena peningkatan spesies ini berkorelasi negatif terhadap diversitas. Tingkat keanekaragaman yang lebih rendah disebabkan adanya tekanan ekologi dari faktor biotik dan abiotik yang (Samin et al. 2016). Keanekaragaman yang rendah umumnya terdapat pada kawasan yang ekstrim unsur hara dan air (Maun 2009). Indriyanto (2006) menjelaskan bahwa diversitas spesies tinggi jika suatu komunitas memiliki banyak spesies di dalamnya.

\section{Kesamaan komunitas}

Indeks kesamaan diperlukan untuk mengetahui kesamaan (kedekatan) komunitas yang berada di beberapa lokasi yang berbeda yang di dasarkan dari banyaknya kesamaan spesies yang dimilikinya. Analisis kluster dengan metode Ward digunakan karena metodenya yang mengkategorikan kluster berdasarkan tingkat keragaman yang sangat rendah. Semakin rendah keragamannya antar komunitas akan memiliki nilai indeks kesamaan yang tinggi.

Analisis indeks kesamaan komunitas dengan menggunajan metode Ward membentuk dua kluster (Gambar 4). Kluster pertama terdiri atas Cagar Alam Air Rami 1 dan Taman Wisata Alam Pantai Panjang dan Pulau Baai dengan nilai indeks kesamaan mencapai 90.5\% dan kluster kedua terdiri atas Cagar Alam Air Seblat terhadap kluster pertama dengan nilai indeks $73.3 \%$. Tingginya indeks yang dihasil menunjukkan bahwa kedua lokasi memiliki spesies yang hampir sama.

Kluster pertama menjelaskan bahwa sekitar 9.5\% spesies di lokasi Cagar Alam Air Rami tidak dimiliki Taman Wisata Alam Pantai Panjang dan Pulau Baai atau sebaliknya. Pada kluster kedua dapat diartikan juga bahwa sekitar 26.7\% spesies dari komunitas tumbuhan tidak dimiliki oleh Cagar Alam Air Seblat dari kluster pertama meskipun ketiga daerah tersebut merupakan kawasan yang sama-sama berada di daerah pesisir. Perbedaan ini dipengaruhi oleh jumlah individu dan spesies yang berbeda. Cagar Alam Air Seblat pada umumnya memiliki indeks keragaman yang rendah bila dibandingkan dengan Cagar Alam Air Rami 1 dan Taman Wisata Alam Pantai Panjang dan Pulau Baai (Tabel 6).

Kondisi lingkungan mempengaruhi indeks kesamaan spesies. Sedikitnya spesies tumbuhan yang hidup di Cagar Alam Air seblat karena kawasan ini pernah mengalami gangguan dari genangan air laut pada tahun 2010 dalam waktu yang lama sekitar satu minggu sehingga menyebabkan beberapa jenis tumbuhan mati termasuk 
diantaranya cemara laut. Selain itu adanya pertambangan pasir, batu dan pembangunan pelabuhan di sekitar kawasan dapat memperburuk kondisi lingkungan sekitar Cagar Alam Air Seblat, sedangkan dua kawasan lainnya memiliki gangguan dari pantai berupa abrasi.

\section{SIMPULAN}

Struktur cemara laut (C. equisetifolia) membentuk kurva $\mathrm{J}$ terbalik meskipun tidak sempurna. Ini disebabkan oleh rendahnya kerapatan pada tingkat pertumbuhan tiang dibandingkan pohon yang dapat dipengaruhi oleh faktor fisiologis, bencana alam dan manusia.

Spesies di kawasan ini disusun oleh 28 genus dari 24 famili tumbuhan. Cemara laut hanya mendominansi pada tingkat pertumbuhan pohon sedangkan tingkat pertumbuhan semai, pancang dan tiang di dominansi oleh nyamplung (C. inophyllum). Dengan demikian ada kecenderungan dominansi cemara laut dapat tergantikan spesies lain di habitatnya.

Indeks keanekaragaman spesies dalam kawasan ini tergolong rendah sampai sedang dengan nilai indeks 1.4 sampai 1.9 yang tersebar hampir merata. Ini dapat menunjukkan bahwa habitat cemara laut juga mendukung spesies lainnya untuk tumbuh.

\section{DAFTAR PUSTAKA}

Diagne N, Diouf D, Svistoonoff S, Kane A, Noba K, Franche C, Bogusz D, Duponnois R. 2013. Casuarinas in Africa: distribution, role and importance of abuscular mycorrhizal, ectomycorrihizal fungi and Frankia on plant development. Journal of Environment Management. 128:204-209.

Diem HG, Duhoux E, Zaid H, Arahous M. 2000. Cluster roots in Casuarinaceae: role and relationship to soil nutrient factors. Annals of Botany. 85:929-936.

Everitt B, Landau S, Leese M, Stahl D. 2011. Cluster Analysis. 5th Edition. Chichester: John Wiley \& Sons.

Eze JMO, Ahonsi MO. 1993. Improved germination of the seeds of whistling pine (Casuarina equisetifolia) forst and forst (Cassuarinaceae) by various presowing treatments. Agronomie. 10(13): 889-894.

Friis IB. 1980. The authority and date of publication of genus Casuarina and its type species. Taxon. 22(4): 499-501.

Golam SAKM, Araki H. 2010. Monotypic taxa, their taxonomic implications and conservation needs in Bangladesh. Proceeding of International Conference on Environmental Aspects of Bangladesh. 10: 5557.

Gould WA, Gonzalez G, Rivera GC. 2006. Structure and composition of vegetation along an elevation gradient in Poerto Rico. Journal of Vegetation Science. 17: 653-664.

Gunawan W, Basuni S, Indrawan A, Prasetyo LB, Soedjito H. 2011. Analisis komposisi dan struktur vegetasi terhadap upaya restorasi kawasan hutan taman nasional gunung gede pangrango. Jurnal Pengelolaan Sumberdaya Alam Lingkungan. 2(1): 93-105.

Hanin A. 2011. Pengaruh Penyiraman air laut terhadap bibit nyamplung (Calophyllum inophylum). Tekno Hutan Tanaman. 4(2): 79-84.

Indriani DW, Marisa H, Zakaria. 2009. Keanekaragaman spesies tumbuhan pada kawasan mangrove nipah (Nypa fruticans Wurmb.) di Kec. Pulau Rimau Kab.Banyuasin Sumatera Selatan. Jurnal Penelitian Sains. 12(3): 1-4.

Indriyanto. 2006. Ekologi Hutan. Jakarta: Bumi Aksara.

Ismaini L, Lailati M, Rustandi, Sunandar D. 2015. Analisis komposisi dan keanekaragaman tumbuhan di Gunung Dempo, Sumatera Selatan. Prosiding Seminar Nasional Masyarakat Biodiversitas Indonesia. 1(6):1397-1402. 
Jamaludheen V, Kumar BM. 1999. Litter of multipurpose trees in Kerala, India: variations in the amount, quality, decay rates and release of nutrients. Forest Ecology and Management. 115:1-11.

Karthikeyan A. 2016. Frankia strains for improving growth, biomass and nitrogen fixation in Casuarina equisetifolia seedlings. Journal of Tropical Forest Science. 28(3): 135-142.

Karthikeyan, A., B. Deeparaj, P. Nepolean. 2009. Reforestation in Bauxite mine spoils with Casuarina equisetifolia frost. And Beneficial Microbes. Forest, Tree and Livehoods 19(2), pp. 153-165.

Koorders SH. 1909. Some systematic and phytogeorgraphical notes the Javanese Casuarinaceae, especially of the State Herbaria at Leiden and at Utrecht. (contribution to the knowledge of the Flora of Java III). Proceedings Royal Netherlands Academy of Art and Sciences. 11: 415-426.

Kusmana C. 1997. Metode Survey Vegetasi. Bogor: Institut Pertanian Bogor Press.

Liu X, Lu Y, Xie Y, Xue Y. 2015. The positive interaction between two nonindigenous species, Casuarina (Casuarina equisetifolia) and Acacia (Acacia mangium), in the tropical coastal zone of south China: stand dynamics and soil nutrients. Tropical Conservation Science. 8(3):598-609.

Ludwig JA, Reynolds JF. 1988. Statistical Ecology a Premier on Methods and Computing. Canada: John Wiley $\&$ Sons.

Magurran AE. 2004. Measuring Biological Diversity. Oxford: Blackwell.

Master J, Tjitrosoedirdjo SR, Qayim I. 2013. Ecological impact of Merremia peltate (L) Merrill Invasion on plant diversity at Bukit Barisan Selatan National Park. Biotropia. 20(1):29-37.

Maun MA. 2009. The Biology of Coastal Sand Dunes. Great Britain: Oxford University Press.

Mligo C, Lyaruu H, Ndangalasi H, Marchant R. 2009. Vegetation community structure, composition and distribution pattern in the Zaraninge Forest, Bagamoyo District, Tanzania. Journal of East African Natural History. 98(2): 223-239.

Mukhlisi, Sidiyasa K. 2011. Aspek ekologi nyamplung (Calophyllum inophyllum L.) di Hutan Pantai Tanah Merah, Taman Hutan Raya Bukit Soeharto. Jurnal Penelitian Hutan dan Konsevasi Alam. 8(3): 385397.

Ngom M, Gray K, Diagne N, Oshone R, Fardoux J, Gherbi H, Hocher V, Svistoonoff S, Laplaze L, Tisa LS, Sy MO, A Champion. 2016. Symbiotic performance of diverse Frankia strains on salt-stressed Casuarina glauca and Casuarina equisetifolia plants. Frontier in Plant Science. 7:1-16.

Nuitja INS, JD Lazell. 1982. Marine turtle nesting in Indonesia. Copeia. 3: 708-710.

Nurfatmah N, Pamoengkas P, Heriansyah I. 2017. Analisis tipologi tutupan vegetasi sebagai dasar penyusunan strategi restorasi di area IUPHHK-RE PT REKI. Jurnal Pengelolaan Sumberdaya Alam dan Lingkungan. 7(1): 41-50.

Romesburg H. 1984. Cluster Analysis for Researchers. California: Wadsworth Inc.

Samin AN, Chairul E, Mukhtar. 2016. Analisis vegetasi tumbuhan pantai pada kawasan wisata Pasir Jambak, Kota Padang. Biocelebes. 10(2):32-42.

Soerianegara I, Indrawan A. 1988. Ekologi Hutan Indonesia. Bogor: Institut Pertanian Bogor Press.

Suwarsono, Supriati, Suwardi. 2011. Zonasi karakteristik kecepatan abrasi dan rancangan teknik penanganan jalan lintas barat Bengkulu bagian utara sebagai jalur transportasi vital. Makara Teknol. 15(1): 31-38.

Tagawa H, Suzuki E, Partomihardjo T, Suriadarma A. 1985. Vegetation and succession on the Krakatau Islands, Indonesia. Vegetation. 60(3): 131-145.

Tani C, Sasakawa H. 2003. Salt Tolerant of Casuarina equisetifolia and Frankia Ceg1 Strain Isolated from the Root Nodules of C. equisetifolia. Soil Science Plant Nutrition. 49(2): 215-222.

Torrey JG. 1982. Casuarina: actinorhizal nitrogen fixing tree of the tropics. In Graham P.H. and Harris S.C. (eds.). Biological Nitrogen Fixation Technology for Tropical Agriculture. 427-439. 